\title{
EFFECT OF PHITOREGULATOR DOSES ON GERMINATION AND VEGETATIVE PHASE OF SOYBEAN WITH LOW PHYSIOLOGICAL QUALITY SEEDS
}

\author{
SANTOS, Elonha Rodrigues \\ OSSANI, Marciano \\ MOREIRA, Andressa Gregolin
}

Recebido em: $2019.05 .22 \quad$ Aprovado em: $2021.02 .08 \quad$ ISSUE DOI: $10.3738 / 1982.2278 .3616$

SUMMARY: The objective of this work was to evaluate seed germination and the initial development of soybean plants with low physiological quality seeds submitted to different doses of phytoregulator. The experiment was carried out from March to April 2018 in Campo Novo do Parecis, MT, Brazil. The experimental design was of completely randomized blocks, in a 3x4 factorial scheme, being three soybean cultivars: Monsoy 7739, Desafio and Monsoy 8372, and four doses of phytoregulator: $0.0 ; 0.5 ; 0.75$ and $1.0 \mathrm{~L} \mathrm{ha}^{-1}$ of Stimulate ${ }^{\circledR}$ composed of cytokinin, indole butyl acid and giberelic acid. Totaling 12 treatments with four replicates. The evaluated variables were: initial germination, final germination, plant height, dry shoot mass, dry root mass and total dry mass. The cultivars responded differently to the phytoregulator doses. The cultivar Monsoy 7739 responded positively to the use of phytoregulator, as it increased germination, presented higher plant height, dry root mass and total dry mass, at the maximum dose of $1.0 \mathrm{~L} \mathrm{ha}{ }^{-1}$. The cultivar Desafio responded negatively to the phytoregulator, as germination presented significant differences compared the other evaluated variables. Monsoy 8372 did not conclusively respond to the use of the phytoregulator conclusively.

Keywords: Germination. Glycine max. Indeterminate soybeans. Plant hormones. Stimulate.

\section{EFEITO DE DOSES DE FITORREGULADORES NA GERMINAÇÃO E NA FASE VEGETATIVA DE SOJA COM BAIXA QUALIDADE FISOLÓGICA DE SEMENTES}

RESUMO: Objetivou-se com este trabalho avaliar a germinação de sementes e o desenvolvimento inicial de plantas de soja com baixa qualidade fisiológica de sementes submetidas a diferentes doses de fitorregulador. $\mathrm{O}$ experimento foi realizado no período de março a abril de 2018 em Campo Novo do Parecis, MT. O delineamento experimental foi de blocos inteiramente casualizados, em esquema fatorial 3x4 sendo três cultivares de soja: Monsoy 7739, Desafio e Monsoy 8372 e quatro doses de fitorregulador: 0,$0 ; 0,5 ; 0,75$ e 1,0 L ha-1 fitorregulador Stimulate ${ }^{\circledR}$ composto por Citocinina, Ácido Indol Butílico e Ácido Giberélico. Totalizando em 12 tratamentos com quatro repetições. As variáveis avaliadas foram: germinação inicial, germinação final, altura de plantas, massa seca da parte aérea, massa seca da raiz e massa seca total. As cultivares responderam de forma diferenciada as doses do fitorrregulador. A cultivar Monsoy 7739 respondeu positivamente ao uso de fitorregulador, pois aumentou a germinação, apresentou maior altura de plantas, maior massa seca de raízes e maior massa seca total na dose máxima de 1,0 L ha-1. A cultivar Desafio respondeu negativamente ao uso do fitorregulador, sendo que a germinação apresentou diferenças significativas das demais variáveis avaliadas. A Monsoy 8372 não respondeu ao uso do fitorregulador de forma conclusiva.

Palavras-chave: Germinação. Glycine max. Hormônios vegetais. Stimulate. 


\section{INTRODUCTION}

Regulators are organic, natural or synthetic compounds acting similarly to plant hormones, and in plant metabolism regulate the growth of various organs. Both natural hormones and synthetic substances exert similar effects to plant hormones and are referred to as plant growth regulators (RODRIGUES; LEITE, 2004). More specifically, plant hormones are chemical messengers, produced in one cell, that modulate cellular processes in another cell, interacting with specific proteins that function as receptors linked to signal transduction routes. Plant development is regulated by six major types of hormones: auxins, gibberellins, cytokinins, ethylene, abscisic acid and brassinosteroids (TAIZ; ZEIGER, 2013).

The biologically active chemical compounds present in germination growth regulators improve seedling performance, speeding the emergence and enhancing seed potential of several species, may cease or decrease the impact of adverse factors on seed quality and performance (ARAGÃO et al., 2003).

Seed performance, physiology of development and consequently soybean (Glycine max L. Merrill) yield are affected by the exogenous application of plant hormones analogues, whether under laboratory, greenhouse or field conditions. Due to the growth of production and the increase of productive capacity, higher economic return from the crop is also sought, for which it is necessary to disclose technologies in the productive sector, such as the use of plant regulators (ALBRECHT et al., 2010).

Studies that analyze the recovery of germination are still scarce in the soybean literature, possibly because Brazilian legislation requires a germination equal to or greater than $80 \%$. However, the use of auxiliary tools for germination recovery is important; these techniques can favor the rescue of cultivars, mainly by plant breeders, without the need for more sophisticated techniques that burden the process. Therefore, the objective of this study was to evaluate the seed germination and the initial development of soybean plants with low physiological quality seeds submitted to different doses of phytoregulator.

\section{MATERIAL AND METHODS}

The experiment was carried out at Ossani Farm, located at latitude 13 56' 41 "S and $57^{\circ} 52^{\prime} 22^{\prime \prime} \mathrm{W}$ with an altitude of $572 \mathrm{~m}$, in Campo Novo do Parecis, MT, Brazil. According to Köppen's precepts, the climate of the region is hot and humid (Aw) (ALVARES et al., 2013). 
The experiment was carried out on March 11, 2018 in 5 L black polyethylene bags. The substrate used was soil + humus (1:1). The humus contained all the macronutrients (nitrogen, phosphorus, potassium, calcium, magnesium and sulfur) and micronutrients (manganese, iron, chlorine, copper, zinc, cobalt, boron molybdenum) and humidifying microorganisms (Rhizobium sp. - nitrogen fixing).

The experimental design was completely randomized in a $3 \times 4$ factorial scheme with four replicates. Factor 1 was composed of three soybean cultivars: Monsoy 7739, Desafio and Monsoy 8372 (Table 1); and factor 2 of four phytorregulator doses: 0,0 (control); 0.5; 0.75 and 1.0 L for 50 $\mathrm{kg}$ of seeds. Twenty-five seeds were sown per pot to perform the germination test until 10 days after sowing (DAS). After the counting of the emerged plants, plants were thinned leaving three plants per pot.

Table 1. Cultivars of soybean studied and their respective characteristics: growing region, growth habit, relative maturity and the company responsible for its launch.

\begin{tabular}{lccc}
\hline Cultivars & Growth habit & Relative maturity* & Company \\
\hline Monsoy 7739 & Determinate & 7.7 & Monsanto \\
Desafio & Indeterminate & 7.4 & Brasmax \\
Monsoy 8372 & Determinate & 8.3 & Monsanto \\
\hline *Maturity Group classification ranging from 4.5 (early) to 9 (late), covering Southern Brazil to Equatorial zone. Source: \\
$\begin{array}{l}\text { Tecnologias de Produção de Soja - Região Central do Brasil 2013. https://www.embrapa.br/busca-depublicacoes/- } \\
\text { /publicacao/975595/tecnologias-de-producao-de-soja---regiao-central-do-brasil-2014. }\end{array}$
\end{tabular}

The phytoregulator used was Stimulate ${ }^{\circledR}$ containing plant hormones based on seaweed extract (Ascophyllum nodosum), 0.009\% kinetin, $0.005 \%$ gibberellic acid and $0.005 \%$ indolebutyric acid. The seeds used were stored for four months at room temperature and humidity (approximately $29^{\circ} \mathrm{C}$ and $60 \% \mathrm{RH}$ ) in Campo Novo dos Parecis, MT, Brazil. The seeds were obtained for sowing in 2017/2018 Brazilian growing season.

Before sowing, the seeds were treated with $250 \mathrm{~mL}$ of Carboxin + Thiram fungicide and 150 $\mathrm{mL}$ of $\mathrm{Co} \mathrm{Mo}\left(15 \% \mathrm{Mo}\right.$ and $\left.1.5 \% \mathrm{Co}^{-1}\right)$ for $100 \mathrm{~kg}$ of seeds. The inoculation with the phytoregulator doses indicated in each treatment was performed using plastic bags, and the content was mixed by hand agitation. The seeds were at rest for one hour to have enough contact with the product. After one hour, the seeds were inoculated with Bradyrhizobium japonicum strains at a dose of $250 \mathrm{~g}$ per $50 \mathrm{~kg}$ of seeds, after which the seeds were sown. 
At sowing, the chemical fertilization was carried out according to the recommendation for potted soybean, using $1.2 \mathrm{~g}$ of urea, $4.0 \mathrm{~g}$ of single superphosphate and $2.0 \mathrm{~g}$ of potassium chloride per pot. The sprinkler irrigation system was adopted, with a daily irrigation frequency until the soil reached 65 to $70 \%$ of the field capacity.

The evaluated characteristics were: a) initial germination (IG): obtained by direct counting of all emerged seedlings at 5 DAS and the data expressed in \%; b) final germination (FG): obtained by direct counting of emerged seedlings at 10 DAS and the data expressed in \%; c) plant height (PH): determined using a graduated ruler measuring from the base to the highest point of the plant, at 30 DAS, in cm; d) shoot dry mass (SDM): determined at 30 DAS, after drying the shoot in a forced ventilation oven at $65^{\circ} \mathrm{C}$ until constant mass, values expressed in $\mathrm{g}$; e) root dry mass (RDM): determined at $30 \mathrm{DAS}$, after drying the roots in a forced ventilation oven at $65{ }^{\circ} \mathrm{C}$ until constant mass, values expressed in $\mathrm{g}$; f) total dry mass (TDM): sum of the shoot and root dry mass, values expressed in $\mathrm{g}$.

The data were submitted to analysis of variance, $F$ test $(\mathrm{p}<0.05)$, and the means compared by the Tukey test.

\section{RESULTS AND DISCUSSION}

There was significant interaction between cultivars and phytoregulator doses for all variables (Table 2). The results showed that the cultivars responded to the phytoregulator doses for initial germination, final germination, plant height, dry shoot mass, dry root mass and total dry mass.

Table 2. Joint analysis of germination and agronomic variables of soybean cultivars submitted to different phytoregulator doses in seed treatment, Campo Novo do Parecis, MT, Brazil, 2018.

Mean square

\begin{tabular}{lccccccc}
\cline { 2 - 7 } Source of Variation & DF & FE & FC & PH & DSM & DRM & DTM \\
\hline Cultivar ( C ) & 2 & $2815.64^{* *}$ & $4343.68^{* *}$ & $20.00^{* *}$ & $2.17^{* *}$ & $3.75^{* *}$ & $10.59^{* * *}$ \\
Phytoregulator dose (P) & 3 & $37.00^{*}$ & $52.05^{*}$ & $10.68^{* *}$ & $0.93^{* *}$ & $0.17^{* *}$ & $1.87^{* *}$ \\
C x P & 6 & $181.64^{* *}$ & $299.57^{* *}$ & $16.00^{* *}$ & $0.35^{* *}$ & $0.09^{* *}$ & $0.40^{* *}$ \\
Residue & 36 & 11.93 & 12.16 & 0.71 & 0.42 & 0.01 & 0.04 \\
\hline Mean & & 25 & 33.25 & 24.56 & 2.73 & 1.79 & 4.52 \\
CV $(\%)$ & & 13.77 & 10.49 & 3.44 & 7.49 & 5.90 & 4.46 \\
\hline
\end{tabular}

$* *$ and $*$ significant at $\mathrm{p} \leq 0.01$ e $\mathrm{p} \leq 0.05$, respectively, by the $\mathrm{F}$ test.

FE: first field emergence counting (\%); FC: final field emergence counting (\%); PH: plant height; DSM: dry shoot mass; DRM: dry root mass; DTM: dry total mass.

Nucleus, v.18, n.1, abr. 2021 


\section{Initial germination}

For initial germination, the cultivar Monsoy 7739 responded gradually to the phytoregulatordoses (Table 3). This indicates that the plant hormones promoted a beneficial effect on seed germination, probably due to the actions of cell division and elongation, and to the increase of gibberellins concentration in the embryo, which is responsible for triggering several biochemical processes in the seed as increasing the synthesis of hydrolytic enzymes that degrade the starch in smaller molecules making it available to the embryo.

Table 3. Mean values for initial germination of soybean seeds, on the fifth day after sowing, submitted to different doses of phytoregulator in seed treatment, Campo Novo do Parecis, MT, Brazil, 2018.

\begin{tabular}{lccccc}
\hline \multirow{2}{*}{ Cultivars } & \multicolumn{5}{c}{ Phytoregulator doses $\left(\mathrm{L} \mathrm{ha}^{-1}\right)$} \\
\cline { 2 - 6 } & 0.0 & 0.5 & 0.75 & 1.0 & Mean \\
\cline { 2 - 6 } & $27 \mathrm{Bb}$ & $40 \mathrm{Aa}$ & $28 \mathrm{Ba}$ & $45 \mathrm{Aa}$ & 35 \\
\hline Monsoy 7739 & $33 \mathrm{Aa}$ & $28 \mathrm{Ab}$ & $32 \mathrm{Aa}$ & $28 \mathrm{Ab}$ & 30 \\
Desafio & $10 \mathrm{ABc}$ & $6 \mathrm{Bc}$ & $15 \mathrm{Ab}$ & $9 \mathrm{ABc}$ & 10 \\
Monsoy 8372 & 23 & 25 & 25 & 28 & - \\
\hline $\begin{array}{l}\text { Mean } \\
\text { Means followed by the same lowercase letter in the column and uppercase letter in the row do not differ by the Tukey } \\
\text { test, at 5\% probability. }\end{array}$
\end{tabular}

The cultivar Desafio did not present significant difference between the phytoregulator doses tested and maintained a germination average of $30 \%$. The initial germination of 'Monsoy 8372' was higher at $0.75 \mathrm{~L} \mathrm{ha}^{-1}$ with a mean of $15 \%$, however, it differed only from the dose of $0.5 \mathrm{~L} \mathrm{ha}^{-1}$; on average this cultivar presented only $10 \%$ of germination.

The cultivar Desafio presented higher initial germination when not treated with phytoregulator, being significantly superior to the other cultivars. For the dose $0.5 \mathrm{~L} \mathrm{ha}^{-1}$, the cultivar Monsoy 7739 obtained germination rate of 40\%, differing significantly from 'Desafio' and 'Monsoy 8372' with 28 and $6 \%$ germination, respectively.

At the dose $0.75 \mathrm{~L} \mathrm{ha}^{-1}$ the cultivar Desafio presented superior germination, being significantly superior to the others. A germination decrease of 12 and 53\% was observed for the cultivars, Monsoy 7739 and Monsoy 8372, respectively, when compared with 'Desafio' at this dose. 
For dose 1 of the phytoregulator, 'Monsoy 7739' presented 45\% of germination, maintaining the superiority compared to 'Desafio' and 'Monsoy 8372', with a germination decrease of 37 and $80 \%$, respectively.

In relation to the initial germination means, 'Monsoy 7739' was generally superior among the doses, presenting an average of $35 \%$ of germination. Cultivars Desafio and Monsoy 8372 presented a decrease of 14 and $71 \%$ of germination, respectively.

\section{Final germination}

Significant effects among the phytoregulator doses were observed for the final germination rate (Table 4). For 'Monsoy 7739', the $1.0 \mathrm{~L} \mathrm{ha}^{-1}$ dose of phytoregulator was significantly higher. At this dose, an increase of $19 \%$ of germination was observed compared to the control (without phytoregulator).

Table 4. Mean values for final seed germination (\%) of soybean submitted to different doses of phytoregulator in seed treatment, Campo Novo do Parecis, MT, Brazil, 2018.

\begin{tabular}{|c|c|c|c|c|c|}
\hline \multirow{3}{*}{ Cultivars } & \multicolumn{5}{|c|}{ Phytoregulator doses $\left(\mathrm{L} \mathrm{ha}^{-1}\right)$} \\
\hline & \multicolumn{5}{|c|}{ Final germination $(\%)$} \\
\hline & 0.0 & 0.5 & 0.75 & 1.0 & Mean \\
\hline Monsoy 7739 & $37 \mathrm{Cb}$ & $48 \mathrm{Ba}$ & $47 \mathrm{Ba}$ & $56 \mathrm{Aa}$ & 47 \\
\hline Desafio & $49 \mathrm{Aa}$ & $37 \mathrm{Bb}$ & $33 \mathrm{Bb}$ & $32 \mathrm{Bb}$ & 38 \\
\hline Monsoy 8372 & $20 \mathrm{Ac}$ & $6 \mathrm{Bc}$ & $19 \mathrm{Ac}$ & $15 \mathrm{Ac}$ & 15 \\
\hline Mean & 35 & 31 & 33 & 34 & \\
\hline
\end{tabular}

Means followed by the same lowercase letter in the column and uppercase letter in the row do not differ by the Tukey test, at $5 \%$ probability.

For 'Desafio', a negative effect on the final germination was observed as the phytorregulator dose increased. This cultivar was significantly superior when sown without the phytoregulator (control). Therefore, the treatment with phytoregulator was not feasible to rescue the seeds germination of this cultivar.

For final germination, 'Monsoy 8372' was superior at the dose 0.0 (control), 0.75 and $1.0 \mathrm{~L}$ $\mathrm{ha}^{-1}$ of phytoregulator, differing significantly from the dose $0.5 \mathrm{~L} \mathrm{ha}^{-1}$. This demonstrates that, possibly, this cultivar did not respond to the treatment of the phytoregulator, since there was no 
significant difference between the dose 0.0 and $1.0 \mathrm{~L} \mathrm{ha}^{-1}$ of phytoregulator. The result found for dose $0.5 \mathrm{~L} \mathrm{ha}^{-1}$ is probably due to the poor physiological quality of the seeds.

For the $0.5 \mathrm{~L} \mathrm{ha}^{-1}$ dose, 'Monsoy 7739 ' showed an increase in the germination rate, differing significantly from 'Desafio' and 'Monsoy 8372'. At the dose $0.75 \mathrm{~L} \mathrm{ha}^{-1}$, 'Monsoy 7739' presented superior germination. There was a decrease in germination of 14 and $28 \%$ for cultivars Desafio and Monsoy 8372, respectively, when compared to Monsoy 7739 at the same dose. For dose $1.0 \mathrm{~L} \mathrm{ha}^{-1}$ of phytogulator, 'Monsoy 7739 ' presented $56 \%$ of germination, maintaining superiority in relation to Desafio and Monsoy 8372.

A difference of $32 \%$ was observed in relation to the cultivars Monsoy 7739 and Monsoy 8372 for the final germination. All cultivars presented a low final germination rate, this may have occurred as a function of seed storage.

\section{Plant height}

Significant effects among the phytoregulator doses tested were observed (Table 5). The cultivar Monsoy 7739 was superior at the dose of $1.0 \mathrm{~L} \mathrm{ha}^{-1}$. 'Desafio' was superior at doses 0.5 and $1.0 \mathrm{~L} \mathrm{ha}^{-1}$, with same height for the two doses $(26 \mathrm{~cm})$.

Tabela 5. Mean values for plant height $(\mathrm{cm})$ of soybean submitted to different doses of phytoregulator in seed treatment, Campo Novo do Parecis, MT, Brazil, 2018.

$$
\text { Phytoregulator doses }\left(\mathrm{L} \mathrm{ha}^{-1}\right)
$$

\begin{tabular}{lccccc}
\cline { 2 - 6 } Cultivars & \multicolumn{5}{c}{ Plant height $(\mathrm{cm})$} \\
\cline { 2 - 6 } & \multicolumn{1}{c}{0.0} & 0.5 & 0.75 & 1.0 & Mean \\
\hline Monsoy 7739 & $25.00 \mathrm{Ba}$ & $25.25 \mathrm{Ba}$ & $24.00 \mathrm{Ba}$ & $27.00 \mathrm{Aa}$ & 25.31 \\
Desafio & $25.00 \mathrm{ABa}$ & $26.00 \mathrm{Aa}$ & $24.25 \mathrm{Ba}$ & $26.00 \mathrm{Aa}$ & 25.31 \\
Monsoy 8372 & $25.75 \mathrm{Aa}$ & $19.00 \mathrm{Cb}$ & $24.25 \mathrm{ABa}$ & $23.25 \mathrm{Bb}$ & 23.06 \\
\hline Mean & 25.25 & 23.41 & 24.16 & 25.41 &
\end{tabular}

Means followed by the same lowercase letter in the column and uppercase letter in the row do not differ by the Tukey test, at $5 \%$ probability.

A negative response was observed for the cultivar Monsoy 8372, as the highest height was observed for dose $0.0 \mathrm{~L} \mathrm{ha}^{-1}$. The low physiological quality of the seeds may be the cause this cultivar did not responded to the hormonal treatment, as it was probably not significant to rescue the physiological quality. 
At the dose of $0.0 \mathrm{~L} \mathrm{ha}^{-1}$, the cultivars did not differ for plant height, averaging $25.25 \mathrm{~cm}$. At $0.5 \mathrm{~L} \mathrm{ha}^{-1}$, the cultivars Monsoy 7739 and Desafio were statistically different from Monsoy 8372. At $0.75 \mathrm{~L} \mathrm{ha}^{-1}$, the cultivars did not differ for plant height, averaging $24,24.25$, and $24.25 \mathrm{~cm}$ for the cultivars Monsoy 7739, Desafio and Monsoy 8372, respectively. At $1.0 \mathrm{~L} \mathrm{ha}^{-1}$, the cultivars Monsoy 7739 and Desafio did not differ, with averages of 27 and $26 \mathrm{~cm}$, but they differed from 'Monsoy 8372 ', which averaged $23.25 \mathrm{~cm}$.

Regarding the general mean of plant height, 'Monsoy 7739' and 'Desafio' did not differ, both presenting the height average of $25.31 \mathrm{~cm}$. 'Monsoy 8372' decreased in height, presenting an average of $23.06 \mathrm{~cm}$.

\section{Dry shoot mass}

For the shoot dry mass (Table 6), the post-analysis of the cultivars within each dose revealed that all cultivars responded to the doses of the phytoregulator. As the dose increased, the shoot dry mass also increased, and the dose of $1.0 \mathrm{~L}$ ha-1 showed the highest dry mass accumulation for all evaluated cultivars. For the cultivars, Monsoy 7739 and Desafio presented the largest increase in shoot dry mass, with 2.95 and 2.94 grams, respectively.

Table 6. Mean values for dry shoot mass (g) of soybean submitted to different doses of phytoregulator in seed treatment, Campo Novo do Parecis, MT, Brazil, 2018.

$$
\text { Phytoregulator doses }\left(\mathrm{L} \mathrm{ha}^{-1}\right)
$$

Cultivars

Drys shoot mass

\begin{tabular}{lccccc} 
& 0 & 0.5 & 0.75 & 1.0 & Mean \\
\cline { 2 - 6 } Monsoy 7739 & $2.87 \mathrm{Aa}$ & $2.87 \mathrm{Aa}$ & $2.93 \mathrm{Aa}$ & $3.11 \mathrm{Ab}$ & 2.95 \\
\hline Desafio & $2.81 \mathrm{Aa}$ & $2.86 \mathrm{Bb}$ & $2.82 \mathrm{Aa}$ & $3.26 \mathrm{Aa}$ & 2.94 \\
Monsoy 8372 & $2.52 \mathrm{Aa}$ & $1.48 \mathrm{Aa}$ & $2.34 \mathrm{Bb}$ & $2.87 \mathrm{Bb}$ & 2.30 \\
\hline Mean & 2.73 & 2.40 & 2.69 & 3.08 &
\end{tabular}

Means followed by the same lowercase letter in the column and uppercase letter in the row do not differ by the Tukey test, at $5 \%$ probability.

\section{Dry root mass}

The cultivar Monsoy 7739 obtained the best average of dry root mass (2.30 g) (Table 7). A positive response to dose utilization was observed. The $1.0 \mathrm{~L} \mathrm{ha}^{-1}$ dose presented the highest accumulation of dry root mass, with 2.67 grams. 
For 'Desafio', no gradual increase of dry root mass was observed with the increase of phytoregulator doses. The $0.75 \mathrm{~L} \mathrm{ha}^{-1}$ dose presented a higher accumulation of dry root mass, being 1.83 grams. Thus, for this cultivar, the highest phytoregulator doses inhibited root growth.

Table 7. Mean values for dry root mass of soybean grown under different doses of phytoregulator in seed treatment, Campo Novo do Parecis, MT, Brazil, 2018.

\begin{tabular}{lccccc}
\hline & \multicolumn{5}{c}{ Phytoregulator doses $\left(\mathrm{L} \mathrm{ha}^{-1}\right)$} \\
\cline { 2 - 6 } Cultivars & 0.0 & 0.5 & 0.75 & 1.0 & Mean \\
\cline { 2 - 6 } & $2.23 \mathrm{Aba}$ & $2.03 \mathrm{Ca}$ & $2.17 \mathrm{Ba}$ & $2.67 \mathrm{Aa}$ & 2.30 \\
\hline Monsoy 7739 & $1.60 \mathrm{Bb}$ & $1.73 \mathrm{ABb}$ & $1.83 \mathrm{Ab}$ & $1.74 \mathrm{ABb}$ & 1.73 \\
Desafio & $1.41 \mathrm{ABc}$ & $1.22 \mathrm{Bc}$ & $1.27 \mathrm{ABc}$ & $1.43 \mathrm{Ac}$ & 1.34 \\
Monsoy 8372 & 1.74 & 1.66 & 1.75 & 1.94 & \\
\hline Mean & 1.74 & & \multicolumn{5}{c}{ Dry root mass } \\
\hline
\end{tabular}

Means followed by the same lowercase letter in the column and uppercase letter in the row do not differ by the Tukey test, at $5 \%$ probability.

For 'Monsoy 8372', a positive effect of doses was observed. The dose $1.0 \mathrm{~L} \mathrm{ha}^{-1}$ presented the highest accumulation of dry root mass for this cultivar, being 1.43 grams. This cultivar did not present significant differences when sown without phytoregulator, therefore, treatment with phytoregulator was not feasible for increasing dry root mass.

\section{Total dry mass}

The cultivars responded to the phytoregulator doses (Table 8). As the dose increased, the total dry mass. The dose $1.0 \mathrm{~L} \mathrm{ha}^{-1}$ promoted the greatest accumulation among the cultivars Monsoy7739, Desafio and Monsoy 8372. The cultivar Monsoy 7739 obtained the highest total dry mass, with 5.79 g. 
Table 8. Mean values for total dry mass (g) of soybean submitted to different doses of phytoregulator in seed treatment, Campo Novo do Parecis, MT, Brazil, 2018.

Phytoregulator doses $\left(\mathrm{L} \mathrm{ha}^{-1}\right)$

\begin{tabular}{lccccc}
\cline { 2 - 6 } Cultivars & \multicolumn{5}{c}{ Total dry mass $(\mathrm{g})$} \\
\cline { 2 - 6 } & 0.0 & 0.5 & 0.75 & 1.0 & Mean \\
\hline Monsoy 7739 & $5.10 \mathrm{Ba}$ & $4.91 \mathrm{Ba}$ & $5.21 \mathrm{Ba}$ & $5.79 \mathrm{Aa}$ & 5.25 \\
Desafio & $4.41 \mathrm{Bb}$ & $4.60 \mathrm{Ba}$ & $4.66 \mathrm{ABb}$ & $5.01 \mathrm{Ab}$ & 4.67 \\
Monsoy 8372 & $3.94 \mathrm{ABc}$ & $2.71 \mathrm{Cb}$ & $3.62 \mathrm{Bc}$ & $4.31 \mathrm{Ac}$ & 3.64 \\
\hline Mean & 6.72 & 4.07 & 4.49 & 5.03 &
\end{tabular}

Means followed by the same lowercase letter in the column and uppercase letter in the row do not differ by the Tukey test, at $5 \%$ probability.

The application of a phytoregulator is efficient when carried out in seed treatment, compared to spraying on the sowing line and spraying at 43 days after sowing (DOURADO NETO et al., 2004). In seed germination, gibberellin acts in opposition to abscisic acid and induces the synthesis of hydrolytic enzymes that degrade nutrient reserves accumulated in the endosperm, providing food and energy to the embryo, supporting and guaranteeing seedling growth (TAIZ and ZEIGER, 2013). Among the factors regulating the germination process, the presence of phytoregulator and the balance between these growth promoters and inhibitors play a very important role (MORAES et al., 2002).

Silva et al. (2008) define phytoregulators as a mixture of two or more plant regulators with other substances, such as amino acids, nutrients, hormones and vitamins, which during the crop development cycle, depending on their composition, concentration and proportion, may stimulate plant growth through greater division, cell elongation and differentiation; and, thereby, increase the nutrient and water absorption capacity, directly reflecting in seed germination, growth and development, flowering, fruiting, senescence and crop yield.

The time and type of phytoregulator application is not yet fully defined. Due to several factors that may influence this process, phytoregulators can be applied via seed treatment or foliar spraying, in certain phenological stages depending on the crop (ÁVILA et al., 2008). According to these authors, well-developed seedlings potentially lead to better growth and early development of the crop, which would create favorable conditions, improving agronomic characteristics as well as yield. 
Dartora et al. (2012) emphasize the importance of the physiological quality of soybean seed, mainly because it influences the costs of production, being the reason is highly recommended to use good quality seeds. To assess seed quality, complementary tests of vigor are necessary, as the germination test has limitations on the differentiation of lots (DUTRA and VIEIRA, 2004).

For Moterle et al. (2011), the fact that hormones do not influence the percentage of germination of soybean seeds can be explained by the accumulation of plant hormones in the tissue. Germination is the first physiological process that will have contact with the product exposed to the plant organism. The following development processes may be more influenced by the action of the product on the tissues in formation.

The results found in the present study for Monsoy 8372 corroborated the results obtained by Vieira (2005), in which the phytoregulator did not significantly affect the physiological quality of soybean and cotton seeds.

According to Leite et al. (2003), joint application of gibberellin and cytokinin in soybean tends to decrease the effects of gibberellin, wheres the number of emerged seedlings decreased as the phytoregulator doses increased. The results obtained for germination of cultivar Desafio corroborate the results observed by these authors, as the phytoregulator used in this research presents these two components in its composition.

The components of the phytoregulators can determine physiological effects and events depending on the cultivar. Abiotic factors that may influence the action of these products should also be considered. The application of phytoregulators on seed surface does not guarantee its total absorption (BUCHANAN et al., 2000). According to these authors, the volume of plant hormones absorbed will depend on the contact surface of the seed and the concentration of the solution. Therefore, the low absorption of the product may compromise efficiency in germination.

Bertolin (2008), working with phytoregulator in seed treatment observed that the application of phytorregulator did not influence plant height.

Regarding the hormones, the gibberellins are responsible for stem growth, or in inhibitory action, being able to revert dwarfism. According to Leite et al. (2003), gibberellin influences seedling growth. Thus, the highest plant height mean verified in this study may have occurred due to the increase in the formation of new cells and the greater cellular elongation in response to gibberellin; and the low heights can be justified by the inhibitory action of gibberellin.

The different responses to the application of the phytoregulator can be related to the factors of elongation and cell division of plant hormones present in the product (TAIZ and ZEIGER, 2013). 
For Monsoy 7739, a positive effect on cell division and elongation is, evidenced by the development and increment of dry mass, whereas the results obtained for cultivars Desafio and Monsoy 8372 suggest that these same plant hormones had an inhibitory action to cell elongation and division.

In a study carried out with the application of a bioregulatory solution on seeds of nine soybean cultivars, Moterle et al. (2011) observed different responses among cultivars. These authors also related the results to the plant hormones present in the phytoregulator and their actions on the germination and vigor of soybean seeds.

\section{CONCLUSIONS}

The cultivars responded differently to the treatment with phytorregulator.

The cultivar Monsoy 7739 responded positively to the use of phytorregulator, as the germination was increased and presented higher plant height, dry root mass and total dry mass at the dose 1.0 $\mathrm{L} \mathrm{ha}^{-1}$.

The cultivar Desafio responded negatively to the use of the phytoregulator in the germination and presented specific differences for the other evaluated variables.

The cultivar Monsoy 8372 did not conclusively respond to the use of the phytoregulator.

\section{REFERENCES}

ALBRECHT, L. P. et al. Desempenho fisiológico das sementes de ervilha tratadas com biorregulador. Comunicata Scientiae, v. 5, n.4, p. 464-470, 2014.

DOI: https://doi.org/10.14295/cs.v5i4.350

ALBRECHT, L. P. et al. Qualidade das sementes de soja produzidas sob manejo com biorregulador. Revista Brasileira de Sementes, v.32, p.39-48, 2010. DOI http://dx.doi.org/10.1590/S010131222010000400005

ALVARES, C. A. Köppen's climate classification map for Brazil. Meteorologische Zeitschrift, v. 6, n. 22, 711-728, 2013. DOI: 10.1127/0941-2948/2013/0507

AFRAIRE, L. R. et. al. Avaliação fisiológica de sementes de arroz submetidas a doses de bioestimulante. Nucleus, v.12, n.1, 2015. DOI: $\underline{\text { htp://dx.doi.org/10.3738/1982.2278.1376 }}$

ARAGÃO, C. A.; DANTAS, B. F.; ALVES, E. Atividade aminolítica e qualidade fisiológica de sementes armazenadas de milho super doce tratadas com ácido giberélico. Revista Brasileira de Sementes, v.25, n.1, p 43-48, 2003. DOI: http://dx.doi.org/10.1590/S0101-31222003000100008.

ÁVILA, M. R. et al. Aplicação de biorreguladores e eficiência agronômica na qualidade de sementes de soja. Revista Scientia Agricola, v. 65, n. 6, p. 604-612, 2008.

Nucleus, v.18, n.1, abr. 2021 
BERTOLIN, D. C. Produção e qualidade de sementes de soja convencional e geneticamente modificada em relação à aplicação via sementes e foliar de produto bioestimulante. Dissertação (mestrado) - Universidade Estadual Paulista. Faculdade de Engenharia de Ilha Solteira. Especialidade: Sistemas de Produção, p. 73p, 2008.

BUCHANAN, B.B.; GRUISSEM, W.; JONES, R.L. Bioquímica e Biologia Molelular de Plantas. Sociedade Americana de Fisiologistas Vegetais. Rockville, Maryland. 1367p. 2000.

DARTORA, J. et al.. Qualidade de sementes comerciais de soja comparada a sementes "salvas" produzidas na safrinha na região oeste do Paraná. Scientia Agraria Paranaensis, v.11, n. 2, p.2350, 2012. DOI: http://dx.doi.org/10.18188/ 1983-1471/sap.v15n4p476-486

DOURADO NETO, D. et al. Aplicação e influência do fitorregulador no crescimento das plantas de milho. Revista da Faculdade de Zootecnia, Veterinária e Agronomia, v. 11, n. 1, p. 93-102, 2004.

ELLI, E. F. et al. Potencial fisiológico de sementes de arroz tratadas com biorregulador vegetal. Revista Ciência Agronômica, v. 47, n. 2, p. 366-373, 2016. DOI: 10.5935/1806-6690.20160043

FESSEL, S.A.; PANOBIANCO, M.; SOUZA, C.R.; VIEIRA, R.D. Teste de condutividade elétrica em sementes de soja armazenadas sob diferentes temperaturas. Bragantia, v.69, n.1, p.207-214, 2010. DOI: http://dx.doi.org/10.1590/S0006-87052010000100026

LEITE, V.M.; ROSELEM, C.A.; RODRIGUES, J.D. Efeitos da giberelina e citocinina no crescimento da soja. Scientia Agricola, v.60, n.3, p.537-541, 2003.

MORAES, C.R.A.; MODOLO, V.A.; CASTRO, P.R.C. Fisiologia da germinação e dominância apical. In: CASTRO, P.R.C.; SENA, J.O.A.; KLUGE, R.A. (Ed.). Introdução à fisiologia do desenvolvimento vegetal. Maringá: Eduem. p.159-178, 2002.

MOTERLE, L. M. et al. Efeito de biorregulador na germinação e no vigor de sementes de soja. Revista Ceres, v. 58, n. 5, p. 651-660, 2011.

PELACANI, R. P. et al. Efeito de biorreguladores na germinação e emergência de sementes de soja com diferentes vigores. Revista Ciências Exatas e da Terra e Ciências Agrárias, v. 11, n. 1, p.6269, 2016.

PRADI, E.V. et al. GA 3 em sementes de tomateiro: efeitos na germinação e desenvolvimento inicial de mudas. Revista de Agricultura Neotropical, v. 3, n. 4, p. 19-23, 2016.

RODRIGUES, T.J.D.; LEITE, I.C. Fisiologia vegetal: hormônios das plantas. Jaboticabal: Funep, p.78, 2004.

SILVA, T.T.A.; et al. Qualidade fisiológica de sementes de milho na presença de bioestimulantes. Ciência e Agrotecnologia, v. 32, p. 840-846, 2008. 
SOUZA NETA, M. L. et al. Efeito residual do tratamento de sementes de maxixe com bioestimulante sob estresse salino. Journal of Seed Science, v.38 n.3, p.219-226, 2016. DOI: http://dx.doi.org/10.1590/2317-1545v38n3163796

TAIZ, L.; ZEIGER, E. Giberelinas: reguladores da altura das plantas e da germinação de sementes. In: Fisiologia vegetal. 5. ed. Porto Alegre: Artmed, Cap. 20, p. 581-617, 2013.

VENDRUSCOLO, E.P. et al. Biorregulador na germinação e desenvolvimento inicial de algodoeiro. Revista de Ciências Agroambientais, v.13, n.2, p.32-40, 2015.

VIEIRA E. L. Stimulate na germinação de sementes, vigor de plântulas e crescimento inicial de plantas de algodoeiro. In: V Congresso Brasileiro de Algodão, Salvador. Anais [...] Embrapa Algodão. p.163-163, 2005. 